\title{
Taxonomic study of Marinomonas strains isolated from the seagrass Posidonia oceanica, with descriptions of Marinomonas balearica sp. nov. and Marinomonas pollencensis sp. nov.
}

\begin{abstract}
Correspondence Antonio Sanchez-Amat antonio@um.es
\end{abstract}

\author{
Elena Espinosa, ${ }^{1}$ Ester Marco-Noales, ${ }^{2}$ Daniel Gómez, ${ }^{1}$ \\ Patricia Lucas-Elío, ${ }^{1}$ Mónica Ordax, ${ }^{2}$ Neus Garcías-Bonet, ${ }^{3}$ \\ Carlos M. Duarte ${ }^{3}$ and Antonio Sanchez-Amat ${ }^{1}$ \\ 1Department of Genetics and Microbiology, University of Murcia, 30100 Murcia, Spain \\ ${ }^{2}$ Centro de Protección Vegetal y Biotecnología, IVIA, 46113 Moncada (Valencia), Spain \\ ${ }^{3}$ Department of Global Change Research, IMEDEA (CSIC-UIB) Instituto Mediterráneo de Estudios \\ Avanzados, 07190 Esporles, Mallorca, Spain
}

The genus Marinomonas comprises Gram-negative bacterial strains distributed in different marine environments (Sanchez-Amat \& Solano, 2005). Most recognized species of the genus have been isolated from seawater samples collected from different geographical locations: Marinomonas communis and $M$. vaga (formerly Alteromonas communis and A. vaga) from the Pacific

The GenBank/EMBL/DDBJ accession numbers for the 16S rRNA gene sequences of strains IVIA-Po- $185^{\top}$, IVIA-Po- $101^{\top}$ and IVIA-Po-186 are EU188441, EU188448 and EU188440, respectively.
Ocean (Baumann et al., 1972; van Landschoot \& De Ley, 1983), Marinomonas pontica from the Black Sea (Ivanova et al., 2005), Marinomonas dokdonensis from the East Sea of Korea (Yoon et al., 2005) and Marinomonas mediterranea and M. aquimarina from the Mediterranean Sea (Solano et al., 1997; Solano \& Sanchez-Amat, 1999; Macián et al., 2005). Some have been isolated from cold environments, such as subantarctic regions [Marinomonas polaris (Gupta et al., 2006) and M. ushuaiensis (Prabagaran et al., 2005)] or sea-ice samples [Marinomonas primoryensis (Romanenko et al., 2003)]. The only species described as being associated 
with higher organisms is Marinomonas ostreistagni (Lau et al., 2006), in addition to some $M$. aquimarina strains (Macián et al., 2005), isolated from oysters.

The marine plant Posidonia oceanica plays an important role in Mediterranean Sea ecosystems. P. oceanica meadows are in recession, although the causes of this process are not well understood (Marbà et al., 2005; Duarte et al., 2004). As part of a study to characterize the microbiota associated with P. oceanica (Marco-Noales et al., 2006), samples of this plant were collected from different $P$. oceanica meadows along the coast of the Balearic Islands from March to November 2004. Samples were transported refrigerated to the laboratory under aseptic conditions. Associated microbiota were recovered by comminuting surface-disinfected leaves, roots or internal parts of rhizomes in small pieces in artificial seawater (ASW; Wolf \& Oliver, 1992), according to the protocol of the EPPO (2004) for sampling plant material. Samples were plated on marine agar (MA; BD) and incubated at $25{ }^{\circ} \mathrm{C}$ for 24-72 h. By using this protocol, several hundred strains were isolated. The aim of the present study was to provide taxonomic characterization of the culturable microbiota associated with $P$. oceanica belonging to the genus Marinomonas.

In a first step, partial sequences of the $16 \mathrm{~S}$ rRNA gene, corresponding approximately to the fragment between nucleotides 70 and 660 of the Escherichia coli gene, were obtained from all the isolated strains by the Molecular Diagnostics Center (MDC, Orihuela, Spain) as described by Martínez-Murcia et al. (1999). DNA sequences were determined by direct sequencing of the PCR products on an ABI 3100 Avant sequencer (Applied Biosystems).

Searches via the BLAST program (Altschul et al., 1997) were performed with the sequences obtained, and those showing higher similarity to $16 \mathrm{~S}$ rRNA gene sequences of Marinomonas species than to any other species were selected. In this way, approximately $15 \%$ of the strains that grew on MA were possible members of the genus Marinomonas. In this study, we report the characterization of strains IVIA-Po- $101^{\mathrm{T}}$, IVIA-Po- $185^{\mathrm{T}}$ and IVIA-Po-186.

Genomic DNA was isolated from the selected strains and the almost-complete 16S rRNA gene was amplified and sequenced by the MDC. The sequences obtained have been deposited in the GenBank database. Phylogenetic analyses based on 16S rRNA gene sequences were conducted by using MEGA version 4 (Tamura et al., 2007). The 16S rRNA gene sequences of the type strains of all recognized Marinomonas species, several related marine bacteria as well as Vibrio cholerae ATCC $14035^{\mathrm{T}}$ as an outgroup were included in the analysis. All sequences were aligned by using the CLUSTAL $\mathrm{W}$ program within the MEGA software package, and distance matrices were generated by calculating the p-distance. Phylogenetic trees were constructed by using the neighbour-joining and maximum-parsimony methods. The reliability of the trees was evaluated by using a bootstrap analysis with 1000 resamplings.
DNA-DNA hybridization was performed by the Identification Services of the Deutsche Sammlung von Mikroorganismen und Zellkulturen. DNA was isolated by using a French pressure cell and was purified by chromatography as described by Cashion et al. (1977). DNA-DNA hybridization was carried out as described by De Ley et al. (1970) under consideration of the modifications described by Huß et al. (1983) by using a Cary 100 Bio UV/Vis spectrophotometer equipped with a Peltierthermostatted $6 \times 6$ multicell changer and a temperature controller with in-situ temperature probe. For determination of the $\mathrm{G}+\mathrm{C}$ content, DNA was isolated, digested with nuclease P1 and dephosphorylated as described by Johnson (1994). The nucleosides obtained were analysed by HPLC (Kumura et al., 1991).

For fatty acid analysis, bacterial isolates were cultivated on MA for $24 \mathrm{~h}$ at $25{ }^{\circ} \mathrm{C}$ prior to fatty acid extraction and methylation according to the Microbial Identification System procedure (MIDI Inc.). Extracted samples were analysed with a Hewlett Packard 5890 gas chromatograph. Fatty acid peaks were identified by the Microbial Identification System version 4, and profiles were compared with the database in the Sherlock System 3.10 (Microbial ID; MIDI Inc.). Unless otherwise indicated, biochemical, microscopic and physiological tests were performed as described by Baumann et al. (1972) and Solano \& Sanchez-Amat (1999). Utilization of different compounds as carbon sources was assayed in BM mineral medium (Baumann et al., 1972; Solano \& Sanchez-Amat, 1999). In these assays, strain IVIA-Po- $101^{\mathrm{T}}$ was unable to grow in BM medium, suggesting that it could be auxotrophic for some growth factors. Medium MM101 was developed for cultivation of strain IVIA-Po- $101^{\mathrm{T}}$ and contained $\left(1^{-1}\right) 40 \mathrm{~g}$ sea salts (Sigma), $1 \mathrm{~g}$ yeast extract and $0.07 \mathrm{~g} \mathrm{~K}_{2} \mathrm{HPO}_{4}\left(\mathrm{pH} \mathrm{7.5)}\right.$. For strain IVIA-Po- $101^{\mathrm{T}}$, its capacity to use a compound as carbon source was determined by comparing growth in MM101 with and without the addition of that compound. Melanin synthesis was evaluated by checking brown to black pigmentation on MA, minimal medium, BM or MM101 depending on the strain, with glutamate as carbon and energy source plus $5 \mathrm{mM}$ L-tyrosine as the substrate for melanogenesis (Solano et al., 1997). Laccase activity was checked on $0.5 \%$ agarose plates containing $1 \mathrm{mM}$ 2,6-dimethoxyphenol as described by Solano et al. (2000). Antimicrobial activity was screened by antibiogram tests against $E$. coli UM202 (Lucas-Elío et al., 2006). Agar plugs from 2-weekold cultures on MA plates of the different Marinomonas strains were placed onto the E. coli lawn and the plates were incubated at $25{ }^{\circ} \mathrm{C}$ for 2 days. In all the tests performed, M. mediterranea MMB- ${ }^{\mathrm{T}}$, from our own laboratory collection, and M. pontica $46-16^{\mathrm{T}}$, a generous gift of E. Ivanova, were used as controls and for comparison. These two strains were chosen because, as described below, they represent the Marinomonas species most closely related to strains IVIA-Po- $101^{\mathrm{T}}$, IVIA-Po$185^{\mathrm{T}}$ and IVIA-Po- 186. 
Table 1 shows differential characteristics between the strains studied. In some tests, all the strains studied gave the same results. For instance, the DNA G $+\mathrm{C}$ content was always below $50 \mathrm{~mol} \%$, as expected for the genus Marinomonas. All the strains required $\mathrm{NaCl}$ for growth and were able to use glucose, glutamate, $\alpha$-ketoglutarate, fructose and malate as carbon sources. By contrast, none was able to use tyrosine, lactose, butyrate or valerate. The predominant cellular fatty acids (Table 2 ) were $\mathrm{C}_{18: 1} \omega 7 c$, $\mathrm{C}_{16: 1} \omega 7 c$ and $\mathrm{C}_{16: 0}$, in accordance with previous results for recognized Marinomonas species (Ivanova et al., 2000; Prabagaran et al., 2005; Yoon et al., 2005; Ivanova et al., 2005). Another abundant fatty acid detected in all strains under our experimental conditions was $\mathrm{C}_{10: 0} 3-\mathrm{OH}$ (6$10 \%$ of the total), indicating that it constitutes a characteristic shared by species in the genus Marinomonas. $\mathrm{C}_{14: 0}$ and $\mathrm{C}_{18: 0}$ were also detected in all strains studied, but at levels below $5 \%$.

Phylogenetic analysis indicated that strains IVIA-Po- $101^{\mathrm{T}}$, IVIA-Po- $185^{\mathrm{T}}$ and IVIA-Po-186 clearly belonged to the genus Marinomonas (Fig. 1). The novel strains clustered with all previously described Marinomonas species in a branch clearly separated from other marine bacteria. This branch was identified with high reliability in the trees constructed by both the neighbour-joining and the maximum-parsimony methods. Within recognized Marinomonas species, IVIA-Po- $185^{\mathrm{T}}$ clearly constitutes a new branch. This strain shared highest 16S rRNA gene sequence similarity (97.4\%) with Marinomonas pontica 46$16^{\mathrm{T}}$. However, DNA-DNA relatedness between the two strains was only $14.5 \%$. According to the recommendations of a threshold value of $70 \%$ DNA-DNA relatedness for the definition of novel species (Wayne et al., 1987), this result indicates that strain IVIA-Po- $185^{\mathrm{T}}$ represents a novel species of the genus Marinomonas. Table 1 shows phenotypic characteristics that can be used to differentiate this strain from recognized Marinomonas species. Characteristics of strain IVIA-Po- $185^{\mathrm{T}}$ that are uncommon in recognized Marinomonas species are the capacity to use $m$-hydroxybenzoate but not maltose as a carbon source. In addition, a unique chemotaxonomic marker of this strain compared with recognized Marinomonas species is the presence of the fatty acid $\mathrm{C}_{17: 0}$ cyclo. Strain IVIA-Po- $185^{\mathrm{T}}$ is thus considered to represent a novel species of the genus Marinomonas, for which the name Marinomonas pollencensis sp. nov. is proposed.

Together with $M$. mediterranea MMB- $1^{\mathrm{T}}$, strains IVIA-Po186 and IVIA-Po- $101^{\mathrm{T}}$ formed a well-defined cluster in the genus Marinomonas (Fig. 1). Strains IVIA-Po-186 and $M$. mediterranea MMB- $1^{\mathrm{T}}$ shared $99.8 \%$ 16S rRNA gene sequence similarity. No phenotypic differences were found between strain IVIA-Po-186 and M. mediterranea MMB- $1^{\mathrm{T}}$ for all the characteristics studied (Tables 1 and 2). $M$. mediterranea is unique in the genus Marinomonas because it shows melanin synthesis due to a tyrosinase (Solano et al., 1997), laccase activity (Sanchez-Amat et al., 2001) and

Table 1. Differential phenotypic characteristics between strains IVIA-Po- $101^{\top}$, IVIA-Po- $185^{\top}$ and IVIA-Po- 186 and the type strains of their closest relatives in the genus Marinomonas

Strains: 1, strain IVIA-Po- $185^{\mathrm{T}}$; 2, M. pontica $46-16^{\mathrm{T}}$ (unless indicated, data from Ivanova et al., 2005); 3, M. mediterranea MMB-1 ${ }^{\mathrm{T}}$; 4, strain IVIAPo-186; 5, strain IVIA-Po- $101^{\mathrm{T}}$. Data are from this study unless indicated. All strains required $\mathrm{NaCl}$ for growth and utilized glucose, glutamate, $\alpha$-ketoglutarate, fructose and malate as carbon sources. None was able to utilize tyrosine, lactose, butyrate or valerate.

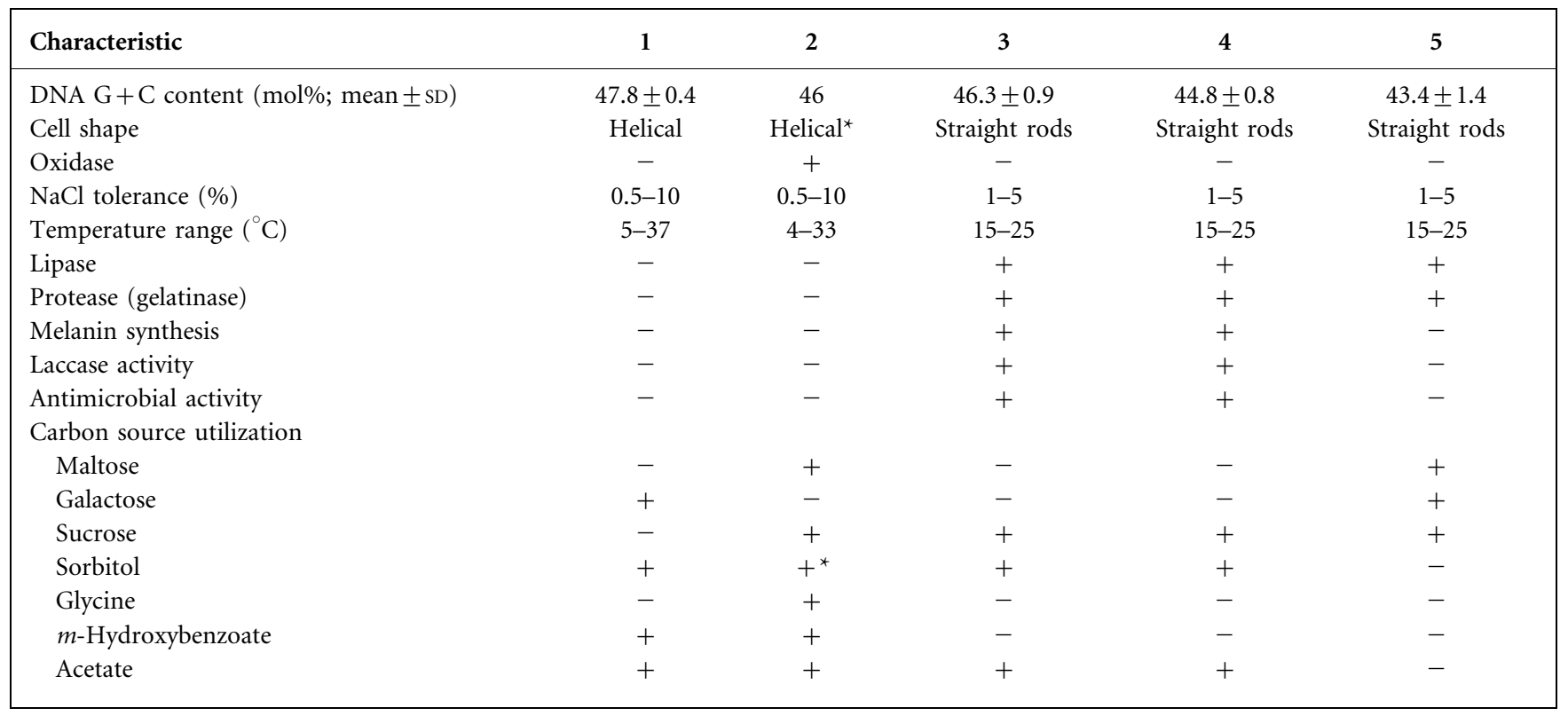

${ }^{\star}$ Data from the present study. 
Table 2. Cellular fatty acid composition of strains IVIA-Po$101^{\top}$, IVIA-Po-185 ${ }^{\top}$ and IVIA-Po-186 and the type strains of related Marinomonas species

Taxa: 1, strain IVIA-Po- $185^{\mathrm{T}} ; 2$, M. pontica $46-16^{\mathrm{T}} ; 3, \quad$. mediterranea MMB- $1^{\mathrm{T}}$; 4, strain IVIA-Po-186; 5, strain IVIA-Po$101^{\mathrm{T}}$. Data are from this study. Values are percentages of total fatty acids. ND, Not detected.

\begin{tabular}{|lccccc|}
\hline Fatty acid & $\mathbf{1}$ & $\mathbf{2}$ & $\mathbf{3}$ & $\mathbf{4}$ & $\mathbf{5}$ \\
\hline $\mathrm{C}_{10: 0} 3-\mathrm{OH}$ & 6.96 & 6.54 & 9.29 & 9.81 & 9.55 \\
Unknown 11.799 & 1.38 & $\mathrm{ND}$ & 5.59 & 6.01 & 5.36 \\
$\mathrm{C}_{12: 0}$ & 9.82 & $\mathrm{ND}$ & $\mathrm{ND}$ & $\mathrm{ND}$ & 0.63 \\
$\mathrm{C}_{12: 1} 3-\mathrm{OH}$ & $\mathrm{ND}$ & 8.40 & $\mathrm{ND}$ & $\mathrm{ND}$ & $\mathrm{ND}$ \\
$\mathrm{C}_{14: 0}$ & 1.22 & 1.60 & 3.14 & 3.85 & 4.21 \\
$\mathrm{C}_{16: 0}$ & 16.53 & 11.73 & 16.20 & 15.02 & 16.61 \\
$\mathrm{C}_{16: 1} \omega 7 c$ & 14.56 & 34.26 & 22.50 & 22.12 & 24.25 \\
$\mathrm{C}_{17: 0}$ cyclo & 3.45 & $\mathrm{ND}$ & $\mathrm{ND}$ & $\mathrm{ND}$ & $\mathrm{ND}$ \\
$\mathrm{C}_{18: 0}$ & 3.72 & 2.27 & 1.72 & 2.63 & 1.48 \\
$\mathrm{C}_{18: 1} \omega 7 c$ & 38.42 & 22.90 & 36.48 & 39.75 & 37.21 \\
\hline
\end{tabular}

an antimicrobial protein with lysine oxidase activity (Lucas-Elío et al., 2006; Gomez et al., 2006). Enzyme assays obtained in this study (data not shown) confirmed that strain IVIA-Po-186 also showed all these enzyme activities. Together, the above results indicate that strain IVIA-Po-186 is a member of $M$. mediterranea. This is the first report of the isolation of a strain of $M$. mediterranea from the microbiota of a plant. The type strain of this species, MMB- $1^{\mathrm{T}}$, was isolated from seawater samples in a different geographical location (Solano et al., 1997), although it was also an area in the Mediterranean Sea with $P$. oceanica meadows. Accordingly, it cannot be ruled out that strain $\mathrm{MMB}-1^{\mathrm{T}}$ was also a component of the microbiota of this seagrass.

Apart from strain IVIA-Po-186, the strain most closely related phylogenetically to $M$. mediterranea is IVIA-Po$101^{\mathrm{T}}$ (Fig. 1). M. mediterranea and strain IVIA-Po- $101^{\mathrm{T}}$ showed lipase and protease activities, characteristics not described for any other Marinomonas species. However, several relevant differential characteristics were found between them. For example, strain IVIA-Po- $101^{\mathrm{T}}$ is the only auxotrophic Marinomonas strain reported so far. With regard to carbon source utilization, strain IVIA-Po- $101^{\mathrm{T}}$ differs from $M$. mediterranea in being able to use maltose and galactose, but not sorbitol or acetate (Table 1). More importantly, in contrast to the results for M. mediterranea strains, we did not detect melanin synthesis or tyrosinase, laccase or lysine oxidase activities in strain IVIA-Po- $101^{\mathrm{T}}$. Strain IVIA-Po- $101^{\mathrm{T}}$ and M. mediterranea MMB- $1^{\mathrm{T}}$ shared $97.9 \% 16 \mathrm{~S}$ rRNA gene sequence similarity. However, the level of DNA-DNA relatedness between the two strains was only $12.6 \%$. According to the recommendations of a threshold value of $70 \%$ DNA-DNA relatedness and the phenotypic differences observed, strain IVIA-Po- $101^{\mathrm{T}}$ is thus considered to represent a novel species of the genus Marinomonas, for which the name Marinomonas balearica sp. nov. is proposed.

This study has revealed that members of the genus Marinomonas form part of the microbiota of the marine plant $P$. oceanica. A strain of $M$. mediterranea has been detected, as well as two other strains representing novel species. Moreover, as a result of this study and the previous characterization of other Marinomonas species, an emended description of the genus is proposed.

\section{Description of Marinomonas balearica sp. nov.}

Marinomonas balearica (ba.le.a'ri.ca. L. fem. adj. balearica related to the Balearic Islands, from where the type strain was isolated).

Cells are Gram-negative rods that are motile by means of a single polar flagellum. Strictly aerobic, catalase-positive and oxidase-negative. Organic growth factors are required. Requires $\mathrm{Na}^{+}$for growth; grows in the presence of $1-5 \%$ $\mathrm{NaCl}$. The temperature range for growth is $15-25^{\circ} \mathrm{C}$. No amylase or agarase activity. Lipase (Tween 80 ) and protease (gelatinase) activities are detected. Glucose, glutamate, $\alpha$ ketoglutarate, fructose, maltose, galactose, sucrose and malate are used as carbon and energy sources, but not sorbitol, glycine, tyrosine, $m$-hydroxybenzoate, acetate, butyrate or valerate. The major fatty acids $(>10 \%$ of the

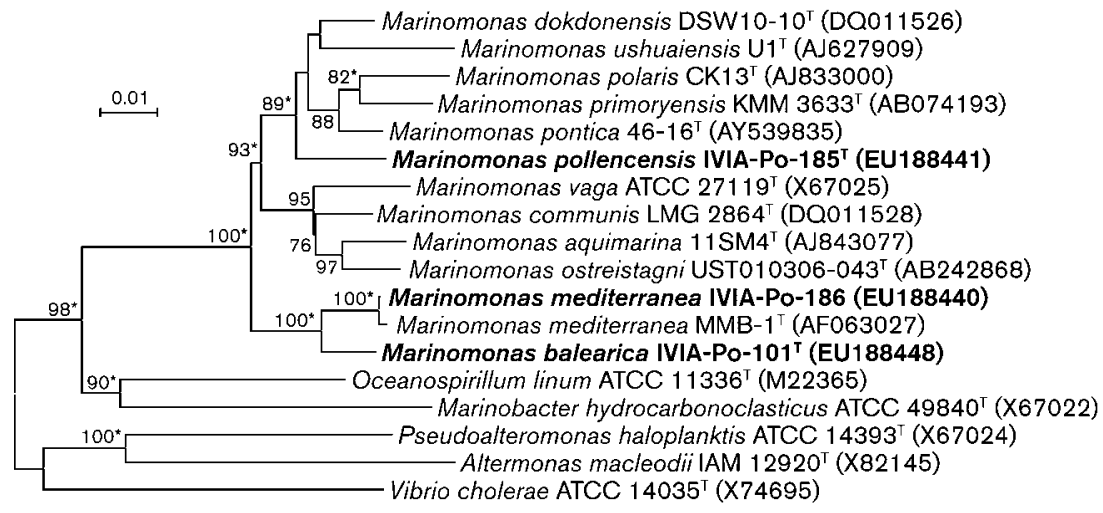

Fig. 1. Consensus neighbour-joining tree based on 16S rRNA gene sequences showing the phylogenetic position of strains IVIA-Po$101^{\top}$, IVIA-Po- $185^{\top}$ and IVIA-Po-186 in relation to the type strains of representative Marinomonas species and other marine bacteria. Numbers at branches indicate bootstrap values (percentages) based on 1000 resamplings; only values $>70 \%$ are shown. Asterisks indicate branches also identified by the maximum-parsimony method. Bar, 1 substitution per 100 nucleotide positions. 
total) are $\mathrm{C}_{18: 1} \omega 7 c, \mathrm{C}_{16: 1} \omega 7 c$ and $\mathrm{C}_{16: 0}$. The DNA G+C content of the type strain is $43.4 \pm 1.4 \mathrm{~mol} \%$.

The type strain, IVIA-Po- $101^{\mathrm{T}}\left(=\mathrm{CECT} 7378^{\mathrm{T}}=\mathrm{NCIMB}\right.$ $14432^{\mathrm{T}}$ ), was isolated from the seagrass Posidonia oceanica.

\section{Description of Marinomonas pollencensis sp. nov.}

Marinomonas pollencensis (pol.len.cen'sis. N.L. fem. adj. pollencensis related to Pollença, the beach in the Balearic Islands from where the type strain was isolated).

Cells are curved, and motile by means of a single polar flagellum. Gram-negative, strictly aerobic, catalase-positive and oxidase-negative. Organic growth factors are not required. Requires $\mathrm{Na}^{+}$for growth; grows in the presence of $0.5-10 \% \mathrm{NaCl}$. The temperature range for growth is $5-$ $37{ }^{\circ} \mathrm{C}$. No amylase, agarase, lipase (Tween 80 ) or protease (gelatinase) activities. Glucose, glutamate, $\alpha$-ketoglutarate, galactose, fructose, sorbitol, $m$-hydroxybenzoate, malate and acetate are used as carbon and energy sources, but not maltose, sucrose, lactose, butyrate, valerate, glycine or tyrosine. The major fatty acids $(>10 \%$ of the total) are $\mathrm{C}_{18: 1} \omega 7 c, \mathrm{C}_{16: 1} \omega 7 c$ and $\mathrm{C}_{16: 0}$. The DNA G $+\mathrm{C}$ content of the type strain is $47.8 \pm 0.4 \mathrm{~mol} \%$.

The type strain, IVIA-Po- $185^{\mathrm{T}}\left(=\mathrm{CECT} 7375^{\mathrm{T}}=\mathrm{NCIMB}\right.$ $14435^{\mathrm{T}}$ ), was isolated from the seagrass Posidonia oceanica.

\section{Emended description of the genus Marinomonas Van Landschoot and De Ley 1984, $91^{\mathrm{VP}}$ (effective publication Van Landschoot and De Ley 1983, 3071)}

Since the description of the genus Marinomonas (Van Landschoot \& De Ley, 1983), which took into consideration the phenotypic characteristics described by Baumann et al. (1972), novel strains and species have been isolated and described. This makes it necessary to emend the description of the genus to include the new data. For instance, for some characteristics, such as amylase, lipase and protease activities, for which the genus was described as negative, positive results have been detected in the novel species.

Members of the genus Marinomonas are Gram-negative, helical, curved or straight rods that are motile by means of polar flagella at one or both poles of the cells. Aerobic, having a strictly respiratory metabolism. Oxidase-positive or -negative. $\mathrm{Na}^{+}$is required for growth. Do not accumulate poly- $\beta$-hydroxybutyrate. Glucose is used by all species and most of them use fructose, glutamate, acetate and malate. Do not utilize butyrate or valerate. Characteristic fatty acids are $\mathrm{C}_{18: 1} \omega 7 c, \mathrm{C}_{16: 1} \omega 7 c, \mathrm{C}_{16: 0}$ and $\mathrm{C}_{10: 0} 3-\mathrm{OH}$. The $\mathrm{G}+\mathrm{C}$ content of the DNA is $41-50 \mathrm{~mol} \%$.

\section{Acknowledgements}

This study was partially supported by grant 03026/PI/05 from the Seneca Foundation, Autonomous Government of the Region of Murcia, and by a grant of Fundación BBVA. We thank Marcelo
Bertazzo, Núria Marbà, María M. López and Begoña Águila-Clares for their assistance and support during this study.

\section{References}

Altschul, S. F., Madden, T. L., Schaffer, A. A., Zhang, J., Zhang, Z., Miller, W. \& Lipman, D. J. (1997). Gapped BLAST and PSI-BLAST: a new generation of protein database search programs. Nucleic Acids Res 25, 3389-3402.

Baumann, L., Baumann, P., Allen, R. D. \& Mandel, M. (1972). Taxonomy of aerobic marine eubacteria. J Bacteriol 110, 402-429.

Cashion, P., Holder-Franklin, M. A., McCully, J. \& Franklin, M. (1977). A rapid method for the base ratio determination of bacterial DNA. Anal Biochem 81, 461-466.

De Ley, J., Cattoir, H. \& Reynaerts, A. (1970). The quantitative measurement of DNA hybridization from renaturation rates. Eur $J$ Biochem 12, 133-142.

Duarte, C. M., Borum, J., Short, F. T. \& Walker, D. I. (2004). Seagrass ecosystems: their global status and prospects. In Aquatic Ecosystems: Trends and Global Prospects, pp. 281-294. Edited by N. V. C. Polunin. Cambridge: Cambridge University Press.

EPPO (2004). EPPO Standards - diagnostic protocols for regulated pests. PM7/20 Erwinia amylovora. Bull OEPP/EPPO Bull 34, 159-171.

Gomez, D., Lucas-Elio, P., Sanchez-Amat, A. \& Solano, F. (2006). A novel type of lysine oxidase: L-lysine-epsilon-oxidase. Biochim Biophys Acta 1764, 1577-1585.

Gupta, P., Chaturvedi, P., Pradhan, S., Delille, D. \& Shivaji, S. (2006). Marinomonas polaris sp. nov., a psychrohalotolerant strain isolated from coastal sea water off the subantarctic Kerguelen islands. Int J Syst Evol Microbiol 56, 361-364.

Huß, V. A. R., Festl, H. \& Schleifer, K. H. (1983). Studies on the spectrophotometric determination of DNA hybridization from renaturation rates. Syst Appl Microbiol 4, 184-192.

Ivanova, E. P., Zhukova, N. V., Svetashev, V. I., Gorshkova, N. M., Kurilenko, V. V., Frolova, G. M. \& Mikhailov, V. V. (2000). Evaluation of phospholipid and fatty acid compositions as chemotaxonomic markers of Alteromonas-like proteobacteria. Curr Microbiol 41, 341345.

Ivanova, E. P., Onyshchenko, O. M., Christen, R., Lysenko, A. M., Zhukova, N. V., Shevchenko, L. S. \& Kiprianova, E. A. (2005). Marinomonas pontica sp. nov., isolated from the Black Sea. Int J Syst Evol Microbiol 55, 275-279.

Johnson, J. L. (1994). Similarity analysis of DNAs. In Methods for General and Molecular Bacteriology, pp. 655-682. Edited by P. Gerhardt, R. G. E. Murray, W. A. Wood \& N. R. Krieg. Washington, DC: American Society for Microbiology.

Kumura, K., Minamishima, Y., Yamamoto, S., Ohashi, N. \& Tamura, A. (1991). DNA base composition of Rickettsia tsutsugamushi determined by reversed-phase high-performance liquid chromatography. Int J Syst Bacteriol 41, 247-248.

Lau, K. W. K., Ren, J. P., Wai, N. L. M., Lau, S. C. L., Oian, P. Y., Wong, P. K. \& Wu, M. (2006). Marinomonas ostreistagni sp. nov., isolated from a pearl-oyster culture pond in Sanya, Hainan Province, China. Int J Syst Evol Microbiol 56, 2271-2275.

Lucas-Elio, P., Gomez, D., Solano, F. \& Sanchez-Amat, A. (2006). The antimicrobial activity of marinocine, synthesized by Marinomonas mediterranea, is due to hydrogen peroxide generated by its lysine oxidase activity. J Bacteriol 188, 2493-2501.

Macián, M. C., Arahal, D. R., Garay, E. \& Pujalte, M. J. (2005). Marinomonas aquamarina sp. nov., isolated from oysters and seawater. Syst Appl Microbiol 28, 145-150. 
Marbà, N., Duarte, C. M., Díaz-Almela, E., Terrados, J., Álvarez, E., Martínez, R., Santiago, R., Gacia, E. \& Grau, A. M. (2005). Direct evidence of imbalanced seagrass (Posidonia oceanica) shoot population dynamics in the Spanish Mediterranean. Estuaries 28, 53-62.

Marco-Noales, E., Ordax, M., Delgado, A., López, M. M., Saavedra, M. J., Martínez-Murcia, A., Garcias, N., Marbà, N. \& Duarte, C. M. (2006). Microbiota associated with Posidonia oceanica in Western Mediterranean sea. In Modern Multidisciplinary Applied Microbiology. Exploiting Microbes and Their Interactions, pp. 114-119. Edited by A. Mendez-Vilas. New York: Wiley.

Martinez-Murcia, A. J., Anton, A. I. \& Rodriguez-Valera, F. (1999). Patterns of sequence variation in two regions of the $16 \mathrm{~S}$ rRNA multigene family of Escherichia coli. Int J Syst Bacteriol 49, 601-610.

Prabagaran, S. R., Suresh, K., Manorama, R., Delille, D. \& Shivaji, S. (2005). Marinomonas ushuaiensis sp. nov., isolated from coastal sea water in Ushuaia, Argentina, sub-Antarctica. Int J Syst Evol Microbiol 55, 309-313.

Romanenko, L. A., Uchino, M., Mikhailov, V. V., Zhukova, N. V. \& Uchimura, T. (2003). Marinomonas primoryensis sp. nov., a novel psychrophile isolated from coastal sea-ice in the Sea of Japan. Int $J$ Syst Evol Microbiol 53, 829-832.

Sanchez-Amat, A. \& Solano, F. (2005). Genus III. Marinomonas Van Landschoot and De Ley $1984,91^{\mathrm{VP}}$ (Effective publication Van Landschoot and De Ley 1983, 3071). In Bergey's Manual of Systematic Bacteriology, 2nd edn, vol. 2, part B, pp. 284-289. Edited by D. J. Brenner, N. R. Krieg, J. T. Staley \& G. M. Garrity. New York: Springer.

Sanchez-Amat, A., Lucas-Elio, P., Fernandez, E., Garcia-Borron, J. C. \& Solano, F. (2001). Molecular cloning and functional characterization of a unique multipotent polyphenol oxidase from Marinomonas mediterranea. Biochim Biophys Acta 1547, 104-116.
Solano, F. \& Sanchez-Amat, A. (1999). Studies on the phylogenetic relationships of melanogenic marine bacteria: proposal of Marinomonas mediterranea sp. nov. Int J Syst Bacteriol 49, 1241-1246.

Solano, F., Garcia, E., de Egea, E. P. \& Sanchez-Amat, A. (1997). Isolation and characterization of strain MMB-1 (CECT 4803), a novel melanogenic marine bacterium. Appl Environ Microbiol 63, 34993506.

Solano, F., Lucas-Elio, P., Fernandez, E. \& Sanchez-Amat, A. (2000). Marinomonas mediterranea MMB-1 transposon mutagenesis: isolation of a multipotent polyphenol oxidase mutant. J Bacteriol 182, 3754-3760.

Tamura, K., Dudley, J., Nei, M. \& Kumar, S. (2007). MEGA4: molecular evolutionary genetics analysis (MEGA) software version 4.0. Mol Biol Evol 24, 1596-1599.

Van Landschoot, A. \& De Ley, J. (1983). Intra- and intergenic similarities of the rRNA cistrons of Alteromonas, Marinomonas (gen. nov.) and some other Gram negative bacteria. J Gen Microbiol 129, 3057-3074.

Wayne, L. G., Brenner, D. J., Colwell, R. R., Grimont, P. A. D., Kandler, O., Krichevsky, M. I., Moore, L. H., Moore, W. E. C., Murray, R. G. E. \& other authors (1987). International Committee on Systematic Bacteriology. Report of the ad hoc committee on reconciliation of approaches to bacterial systematics. Int J Syst Bacteriol 37, 463-464.

Wolf, P. W. \& Oliver, J. D. (1992). Temperature effects on the viable but non-culturable state of Vibrio vulnificus. FEMS Microbiol Ecol 101, 33-39.

Yoon, J. H., Kang, S. J. \& Oh, T. K. (2005). Marinomonas dokdonensis sp. nov., isolated from sea water. Int J Syst Evol Microbiol 55, 23032307. 